\title{
Young people's participation in civil society and political life in Maharashtra
}

International Institute for Population Sciences (IIPS)

Follow this and additional works at: https://knowledgecommons.popcouncil.org/departments_sbsr-pgy

Part of the Demography, Population, and Ecology Commons, Family, Life Course, and Society Commons, Gender and Sexuality Commons, International Public Health Commons, Medicine and Health Commons, and the Sociology of Culture Commons How does access to this work benefit you? Let us know!

\section{Recommended Citation}

International Institute for Population Sciences (IIPS). 2008. "Young people's participation in civil society and political life in Maharashtra," Youth in India: Situation and Needs Policy Brief no. 1. Mumbai: IIPS.

This Brief is brought to you for free and open access by the Population Council. 


\section{Young people's participation in civil society and political life in Maharashtra}

\begin{abstract}
YOUTH PARTICIPATION IN CIVIL SOCIETY
AND POLITICAL LIFE is increasingly recognised as an important development objective. The opportunities for participation that young people experience in their communities may influence their development and the types of transitions they make to adulthood. For example, evidence that comes largely from developed countries indicates that youth who participate in community activities or are connected to their communities are less likely than others to engage in risk-taking behaviours. Moreover, behaviours and attitudes relating to community participation that individuals adopt as young people predict lifelong civic affiliations and perspectives. ${ }^{1}$
\end{abstract}

In India, the National Youth Policy 2003 has underscored the role of India's youth in political decision-making, and has argued for greater representation of youth in appropriate bodies as well as more extensive youth participation in the design and implementation of programmes. ${ }^{2}$ Indeed, there is a recognition that today's youth, who have better access to skills and information than those of earlier generations, can play an important role in influencing political processes and the socio-economic development of the country. However, evidence that sheds light on the extent to which youth participate in civil society and political life remains limited in India.

This policy brief documents the participation of youth in Maharashtra in civil society, the extent to which they uphold secular attitudes, and their perceptions about and participation in political processes in Maharashtra.
The study

The Youth in India: Situation and Needs study is a sub-nationally representative study undertaken for the first time in India of key transitions experienced by young people in six states of India, including Maharashtra. The study included a representative survey of young people in both rural and urban settings. Respondents included unmarried females and males and married females aged 15-24 and, in view of the paucity of married males in these ages, married males aged 15-29.

In Maharashtra, the survey was conducted in 2006. A total of 7,570 married and unmarried young women and men were interviewed in the survey. These included 1,947 married young women, 2,541 unmarried young women, $1,065^{3}$ married young men and 2,017 unmarried young men.

What extent do young people participate in civil society?

Participation in civil society, as measured by participation in community-led activities and membership in organised group, was far from universal among young people, particularly among young women. For example, $63 \%$ of young men compared to $27 \%$ of young women reported that they had participated in any community-led programmes such as cleanliness drives, health promotion activities, and celebration of festivals and national days. Likewise, just $21 \%$ of young men and $8 \%$ of young women reported membership in an organised group, ranging from self-help groups to sports and social clubs. In total, $66 \%$ of young

${ }^{1}$ National Research Council and Institute of Medicine. 2005. Growing up Global: The Changing Transitions to Adulthood in Developing Countries, Washington, D.C.: The National Academies Press.

${ }^{2}$ Ministry of Youth Affairs and Sports. 2003. National Youth Policy 2003, New Delhi: Government of India.

${ }^{3}$ Of the 1,065 married men, 319 were aged 15-24. 
men and $31 \%$ of young women reported participation in civil society.

Findings indicate that participation in civil society was far more likely to be reported by better than less educated youth, and far more likely to be reported by those who were regularly exposed to mass media than those who were not. For example, $55 \%$ of young men with less than 9 years of schooling compared to $71 \%$ of those with at least 9 years of schooling reported participation in civil society. The corresponding percentages among young women were $23 \%$ and $36 \%$. Likewise, the percentage of young men who reported participation in civil society increased from $64 \%$ among those who were not regularly exposed to mass media to $71 \%$ among those who were regularly exposed. Similar differences were evident among young women as well.

Extent of participation in civil society did not differ by current work status of young people. For example, an equal proportion $(66 \%)$ of currently working and not working young men reported participation in civil society. The corresponding percentages among young women were $35 \%$ and $30 \%$, respectively.
Findings also show that unmarried youth were more likely than married youth to report participation in civil society. Two-thirds of unmarried young men compared to three-fifths of married young men reported such participation. Among young women, the unmarried were twice as likely as the married to have participated in civil society.

Finally, findings show that rural youth were more likely than urban youth to have participated in civil society; $81 \%$ of rural young men compared to $48 \%$ of urban young men, and $37 \%$ of rural young women compared to $24 \%$ of urban young women reported participation in civil society.

\section{Do young people uphold secular attitudes?} In order to gauge the extent to which young people uphold secular attitudes, two issues were addressed. The first assessed young people's attitudes regarding social interaction with individuals of different castes and religions. Specifically, youth were asked whether they mixed freely and would eat together with a person from a different caste or religion, and would talk to someone who had an inter-caste marriage.

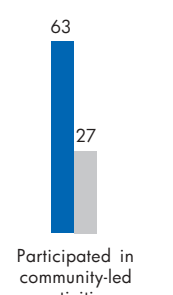
activities
anmunity-led
a
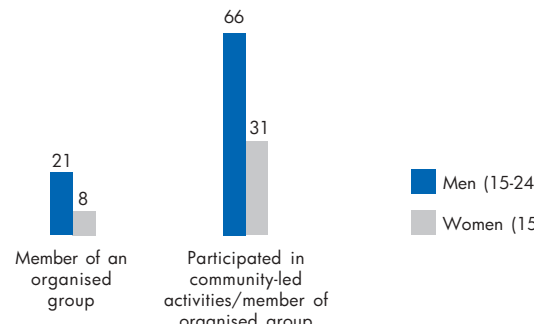

Women (15-24)

activities/member of
organised group
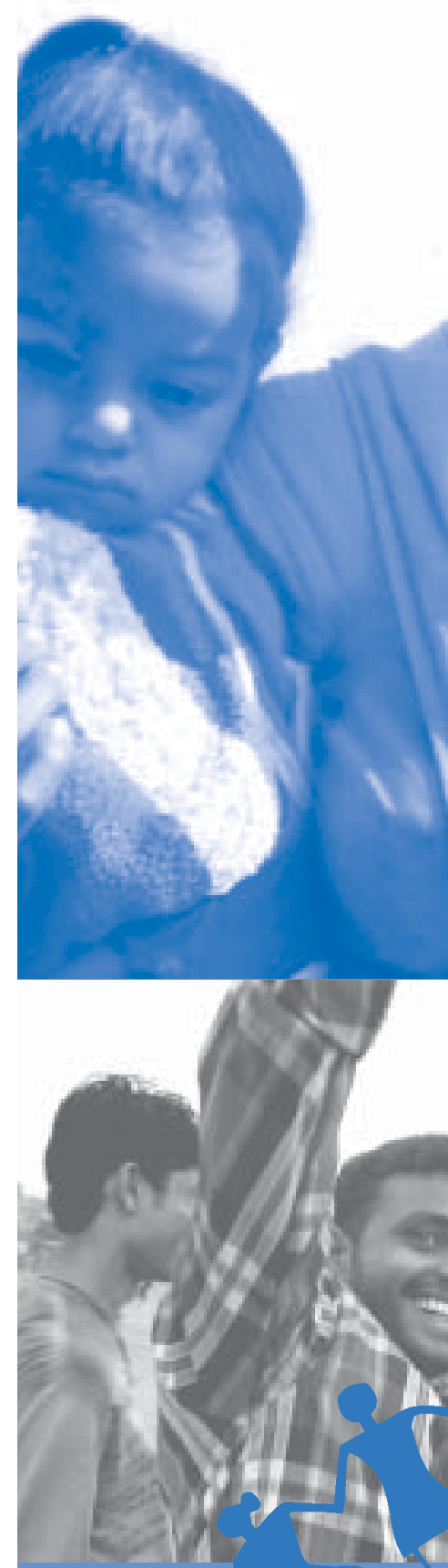

Percentage of youth participating in civil society, according to selected characteristics
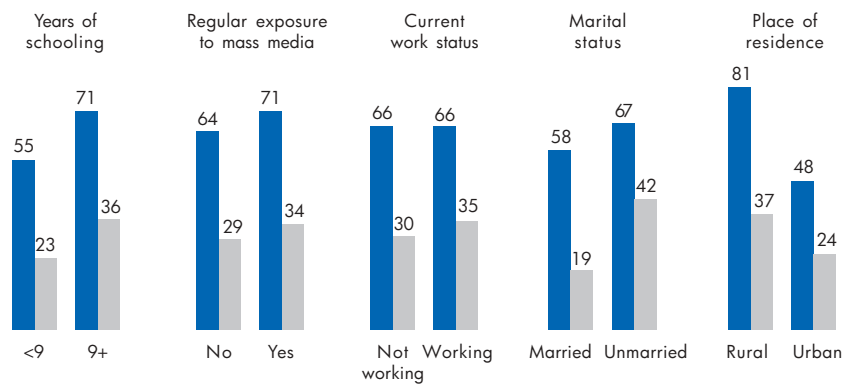

Men (15-24) 
The second assessed young people's tolerance in situations characterised by religious disharmony. Specifically, youth were asked whether or not they considered it acceptable to punish someone who insulted their religion.

Findings show that, by and large, youth upheld secular attitudes about social interaction with individuals of different castes and religions. Indeed, $90 \%$ or more youth reported that they mixed freely with individuals of different religions and castes. Similarly, over $90 \%$ of young men and three-quarters of young women reported that they would eat together with a person from a different caste or religion, and they would talk to someone who had an intercaste marriage.
Despite this relatively secular profile, few young people reported tolerant attitude in situations characterised by religious disharmony. Just 19\% of young men and $22 \%$ of young women considered it unacceptable to retaliate, through punitive action, against someone who insulted their religion.

\section{What do young people think about commitments of political parties and elections?}

A large majority of young people reported disillusionment with the commitment of political parties to work for change at the community level. As many as $80 \%$ of young men and $75 \%$ of young women believed that there would be no improvement in their village (rural youth) or

\section{Percentage of youth expressing secular attitudes about social interaction}

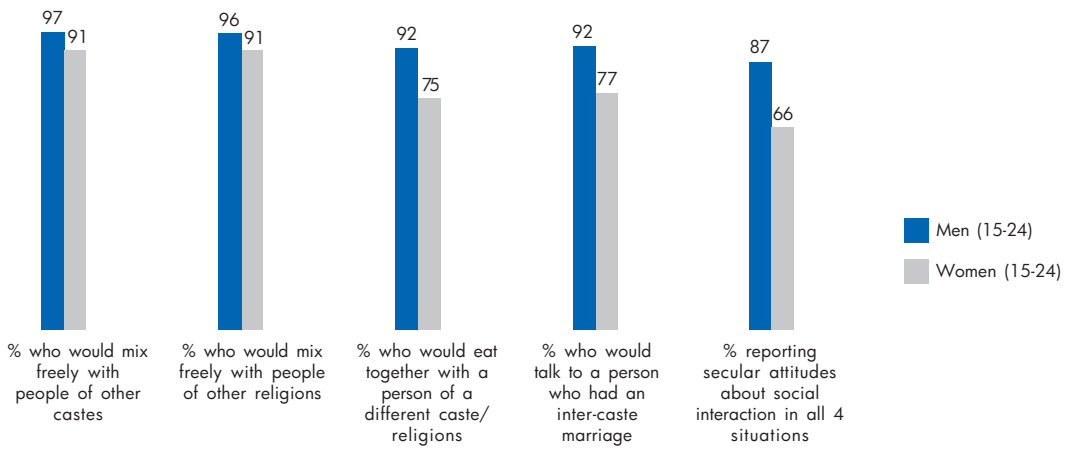

Indeed, $87 \%$ of young men and $66 \%$ of young women reported affirmatively to all four items. Better educated youth were more likely than the less educated to report so; $91 \%$ of young men with at least 9 years of schooling compared to $79 \%$ of those with less than 9 years of schooling reported secular attitudes in all four situations. The corresponding percentages among young women were $73 \%$ and $55 \%$, respectively. Likewise, youth who were regularly exposed to mass media were more likely than those who were not exposed to report secular attitudes in all four situations. Working youth were slightly less likely than those not working to display secular attitudes about social interaction and rural youth were considerably less likely than urban youth to do so. neighbourhood (urban youth) no matter which political party governed the state. Such disillusionment prevailed among both rural and urban youth.

It is notable, however, that most young people (over $80 \%$ ) perceived that the electoral process was fair and one could vote without fear or pressure.

Do young people exercise their voting rights? Findings show that young people's participation in political processes was far from universal. Of those aged 20 years and above, $68 \%$ of young men and $57 \%$ of young women had cast their vote in the most recent election for which they were eligible to vote. 
Percentage of youth expressing secular attitudes, according to selected characteristics

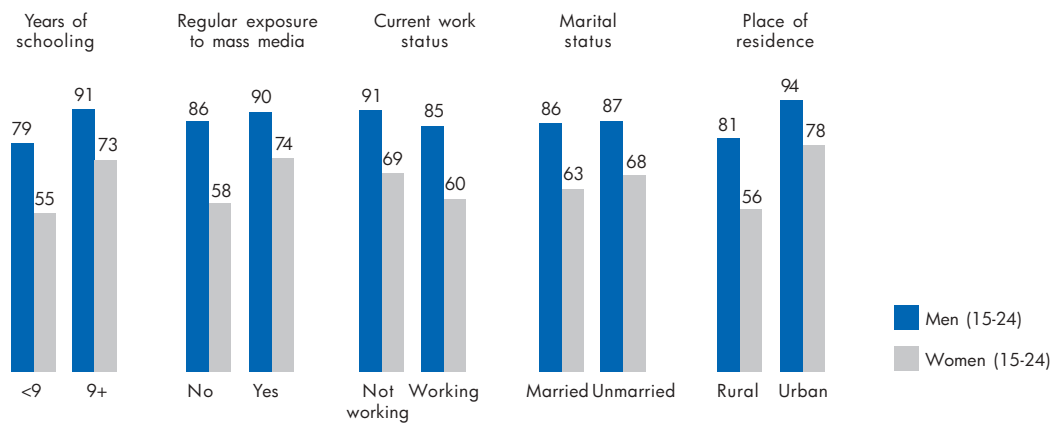

Percentage of youth aged 20 and above who voted in the most recent election, according to selected characteristics

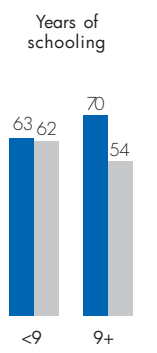

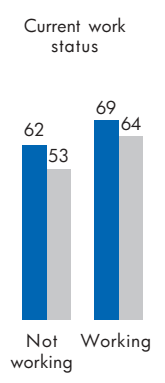
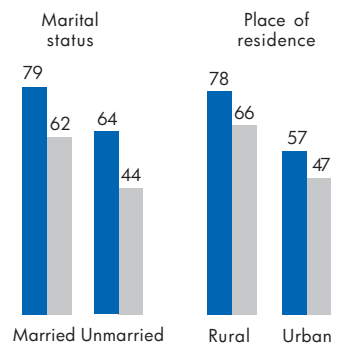

Men (15-24)

Women (15-24)

While better educated young men were more likely than the less educated to have cast their vote in the most recent election, the reverse pattern was observed among young women. Voting behaviour was not associated with exposure to mass media among young men. In contrast, among young women, those who were regularly exposed to mass media were less likely than those who were not to cast their vote.

Among both young men and women, youth who were currently working were somewhat more likely to have voted than those who were not, married youth were far more likely to have voted than the unmarried, and rural youth were considerably more likely than urban youth to have cast their vote in the most recent election.

\section{Programme recommendations}

Findings suggest that for many youth, opportunities to engage in civil society and political life are limited and secular attitudes are not uniformly observed.

Programmes are needed - at the school, college and community levels, through national service programmes, sports and other non-formal mechanisms - that encourage civic participation, incorporate value building components and reinforce secular attitudes and values that espouse responsible citizenship. These efforts must pay special attention to young women, particularly the married.

Suggested citation: International Institute for Population Sciences (IIPS) and Population Council. 2008. Young people's participation in civil society and political life in Maharashtra. Youth in India: Situation and Needs 2006-2007. Mumbai. IIPS.

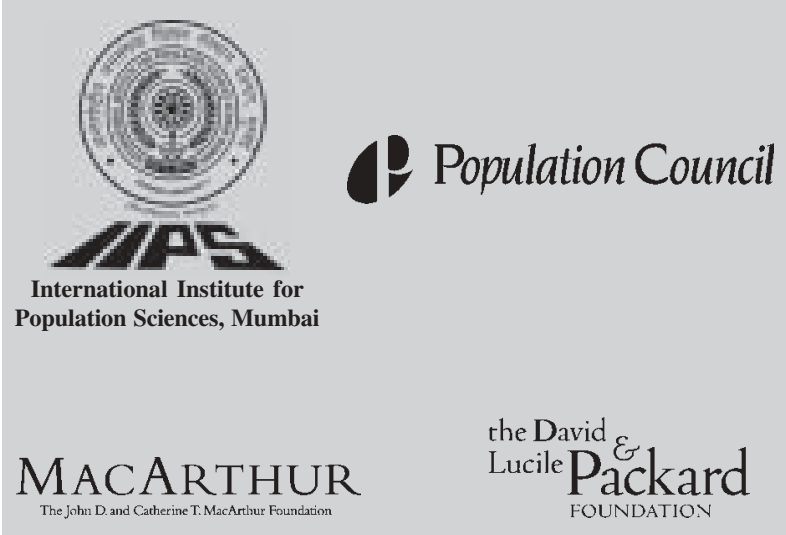

The opinions expressed in this publication do not necessarily reflect the views of the funding agencies.

For additional information on the study, please send an e-mail to iipsyouth@rediffmail.com or info-india@popcouncil.org 